Kohut I, Marynych V, Chebanova K. Inclusive education introduction in physical culture and health related, sports and other educational institutions. Theory and Methods of Physical education and sports. 2020; 1: 117-127

DOI: 10.32652/tmfvs.2020.1.117-127
Когут I, Маринич В, Чебанова К. Впровадження інклюзивного навчання у фізкультурно-оздоровчі, спортивні та інші заклади освіти. Теорія і методика фрізичного виховання і спорту. 2020; 1: 117-127 DOI: $10.32652 /$ tmfvs.2020.1.117-127

\title{
ВПРОВАДЖЕННЯ ІНКЛЮЗИВНОГО НАВЧАННЯ У ФІЗКУЛЬТУРНО-ОЗДОРОВЧІ, СПОРТИВНІ ТА ІНШІ ЗАКЛАДИ ОСВІТИ
}

\section{Ірина Когут, Вікторія Маринич, Катерина Чебанова}

Національний університет фізичного виховання і спорту України, Київ, Україна

\begin{abstract}
Анотація. Нині у більшості країн Європи, в тому числі й в Україні, відбуваються значні зміни у законодавстві щодо розуміння і забезпечення якісної освіти для дітей з особливими освітніми потребами. Аналіз даних Міністерства соціальної політики України свідчить, що станом на 2017 р. кількість людей з інвалідністю у відносному підрахунку збільшилася вдвічі порівняно з 1990 р. Важливим питанням для цієї категорії населення $€$ рівний доступ до всіх можливостей сучасної цивілізації, починаючи з вільного пересування і закінчуючи освітою і працевлаштуванням. Мета. Виявити проблеми та перспективи розвитку інклюзивної освіти в Україні. Методи. Аналіз та узагальнення науково-методичної літератури і матеріалів мережі Інтернет, порівняльний аналіз, вивчення нормативно-правових актів. Результати. У розвинених країнах Європи інклюзивне навчання в освітніх закладах є проявом демократії. Установлено, що в Україні останніми роками в напрямі розвитку інклюзивної освіти досягнуто певних успіхів: на законодавчому рівні закріплено право створювати в закладах середньої освіти спеціальні та інклюзивні класи; ухвалено ряд нормативно-правових актів, спрямованих на реалізацію норм і положень законодавства. Незважаючи на пожвавлення роботи із запровадження інклюзивної освіти й певні успіхи на цьому шляху, є чимало перешкод для її успішного розвитку. В Україні необхідно здійснити такі заходи: продовжувати законодавче оформлення цієї системи навчання; приділяти особливу увагу додатковій освітянській підготовці вчителів, які працюють з дітьми з інвалідністю; внести фрінансування інклюзивної освіти до переліку захищених статей Закону України «Про Державний бюджет України». Ключові слова: діти з особливими потребами, інвалідність, інклюзивна освіта, навчальний заклад, фрізична культура і спорт.
\end{abstract}

\section{Iryna Kohut, Viktoria Marynych, Kateryna Chebanova INCLUSIVE EDUCATION INTRODUCTION IN PHYSICAL CULTURE AND HEALTH RELATED, SPORTS AND OTHER EDUCATIONAL INSTITUTIONS}

\begin{abstract}
Currently, in most European countries, including Ukraine, there are significant changes in legislation regarding the understanding and provision of quality education for children with special educational needs. Analysis of data of the Ministry of Social Policy of Ukraine shows that as of 2017, the number of people with disabilities in relative terms has doubled compared to 1990. An important issue for this population is equal access to all opportunities of modern civilization, from free movement to education and employment. Objective. Identify problems and prospects for the development of inclusive education in Ukraine. Methods. Analysis and generalization of scientific and methodological literature and materials of the Internet, comparative analysis, study of legislative acts. Results. In the developed countries of Europe, inclusive education in educational institutions is a manifestation of democracy. It is established that in Ukraine in recent years some success has been achieved in the development of inclusive education: at the legislative level the right to create special and inclusive classes in secondary education was enshrined; a number of normative legal acts aimed at the implementation of norms and provisions of legislation have been adopted. Despite the revival of inclusive education and some progress, there are many obstacles to its successful development. In Ukraine, the following measures need to be taken: to continue the legislative design of this education system; pay special attention to additional educational training of teachers who work with children with disabilities; to include financing of inclusive education in the list of protected articles of the Law of Ukraine «On the State Budget of Ukraine».
\end{abstract}

Keywords: children with special needs, disability, inclusive education, educational institution, physical culture and sport.

Вступ. В Україні однією із форм навчання дітей з інвалідністю є інклюзивна освіта, яка відносно нова у нашій державі, але вже визнана в багатьох країнах світу. Інклюзивна освіта забезпечує безумовне право кожної дитини навчатися в закла- ді освіти за місцем проживання із забезпеченням усіх необхідних для цього умов [3, 15, 16, 42-44].

Аналіз наукової літератури та матеріалів мережі Інтеренет дозволяє стверджувати, що проблема інклюзії дітей з особливими освітніми потребами в 
український освітній простір є актуальною та багатогранною і розглядається вітчизняними, так і зарубіжними науковцями [1, 42-44, 46-48]. Вони в своїх дослідженнях розглядають інклюзію в освіті як один із багатьох аспектів інклюзії в суспільстві загалом, наголошуючи, що інклюзія означає розкриття кожної особистості за допомогою освітньої програми [1, 46-48]. У зв'язку з цим в Україні постало важливе питання запровадження інклюзивного навчання, формування нової філософії державної політики щодо дітей з інвалідністю, вдосконалення і розвиток нормативно-правової бази відповідно до міжнародних документів у сфері прав людини.

Роботу виконано в рамках теми 1.7. «Організаційно-методичні основи розвитку адаптивного спорту» тематичного плану науково-дослідної роботи в сфері фізичної культури і спорту на 20162020 рр. Міністерства освіти і науки України (номер держреєстрації 0116U001613).

Мета дослідження - визначення проблем та перспектив розвитку інклюзивної освіти, в тому числі в закладах фізкультурно-спортивного профілю, в Україні на основі аналізу особливостей їі впровадження на міжнародному та національному рівнях.

Методи дослідження: аналіз та узагальнення науково-методичної літератури та матеріалів мережі Інтернет, порівняльний аналіз, вивчення нормативно-правових актів.

Результати дослідження та їх обговорення. Інформацію 3 нормативно-правових аспектів інклюзивної освіти було отримано з Бази даних законодавства України. Вперше інклюзія була закріплена в Загальній декларації прав людини у 1948 р. і згодом знаходить відображення в усіх міжнародних документах у сфері освіти. У різних країнах світу інклюзія впроваджується вже не один десяток років та є світовою тенденцією, яка певною мірою віддзеркалює рівень цивілізованості суспільства тієї чи іншої держави [47].

Західноєвропейські системи загальної середньої освіти, незважаючи на різноманітність типів і рівнів навчальних закладів, які опікуються освітою, в тому числі й дітей з інвалідністю, є ключовими елементами сучасної європейської моделі соціального устрою. Ця модель приваблива для країн, що позбулися тоталітарних режимів, а наразі й для України, з огляду на завдання та перспективи вирішення назрілих педагогічних і соціальних проблем [46].

У передових країнах Західної Свропи, починаючи $з$ 1970-х років, відбувалася перебудова спеціальної освіти. Зокрема, інтегроване та інклюзивне навчання дітей з інвалідністю визначено як основну форму здобуття загальної освіти.

Серед країн із найбільш досконалим і розвиненим законодавством у галузі інклюзивної освіти найчастіше називають Канаду, Кіпр, Данію, ПАР, Іспанію, Бельгію, Швецію, Велику Брита-

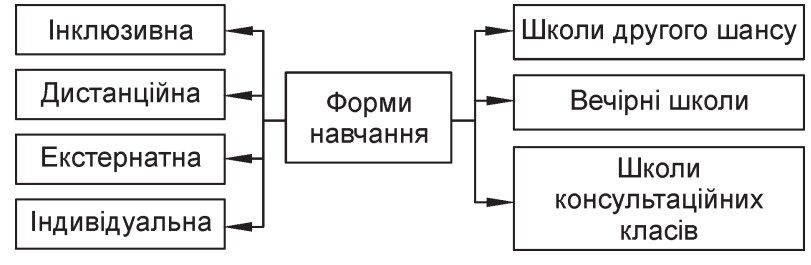

Рисунок 1 - Основні форми здобуття освіти для людей з інвалідністю у країнах Європи [2]

нію, США. Наприклад, в Італії законодавство підтримує інклюзивну освіту з 1971 р. До того ж акцент зроблено не на навчанні, а на соціалізації. В результаті діти з інвалідністю стають повноцінними членами суспільства. У Фламандській частині Бельгії давно діє добре розвинена система спеціальних шкіл, фахівці яких супроводжують дітей з інвалідністю під час інтеграційних процесів у загальноосвітніх школах. У цих і багатьох інших країнах інклюзивна освіта існує вже 30-40 років [48].

Для забезпечення права на якісну освіту дітей з особливими освітніми потребами міжнародна практика пропонує їм широкий вибір доступних форм здобуття освіти (рис. 1).

В Україні спеціальна освіта має складну розгалужену й диференційовану систему навчальновиховних (корекційних) закладів, реабілітаційних і медико-педагогічних центрів, навчально-виховних комплексів, спеціальних (корекційних) класів при середніх закладах освіти тощо. Розвиток системи спеціальної освіти спрямований на подальшу диференціацію і вдосконалення діючої мережі корекційних закладів, відкриття нових типів закладів, у яких надаватимуться комплексна допомога й підтримка дітям із особливими освітніми потребами, а також із залученням цих дітей у загальноосвітню школу [19].

Закони України «Про освіту» [7] та «Про загальну середню освіту» [6] надають можливість батькам дітей 3 особливими освітніми потребами варіанти вибору різних форм навчання (в спеціальній школі; школі-інтернаті; навчальнореабілітаційному центрі; у корекційних класах при загальноосвітній школі, дитсадку-школі; домашнє навчання; у формі екстернату тощо).

В Україні ситуація із запровадженням інклюзивної освіти знаходиться на етапі створення підгрунтя для ефективного впровадження. Станом на 2017 р., серед 17337 українських шкіл тільки 1127 залучені до реалізації інклюзивної освіти. Понад 56 тис. школярів 3 особливими освітніми потребами не мають можливості навчатися в загальноосвітніх закладах. За даними Державної служби статистики України [14], показник інклюзії в Україні становить лише 7 \%. Для порівняння: в Італії ця цифра охоплює $99 \%$, Норвегії - $90 \%$, Литві - 90 \%, Угорщині - 57 \%, Польщі - $42 \%$, Словаччині - 42 \%, Франції - 25 \% [47]. 


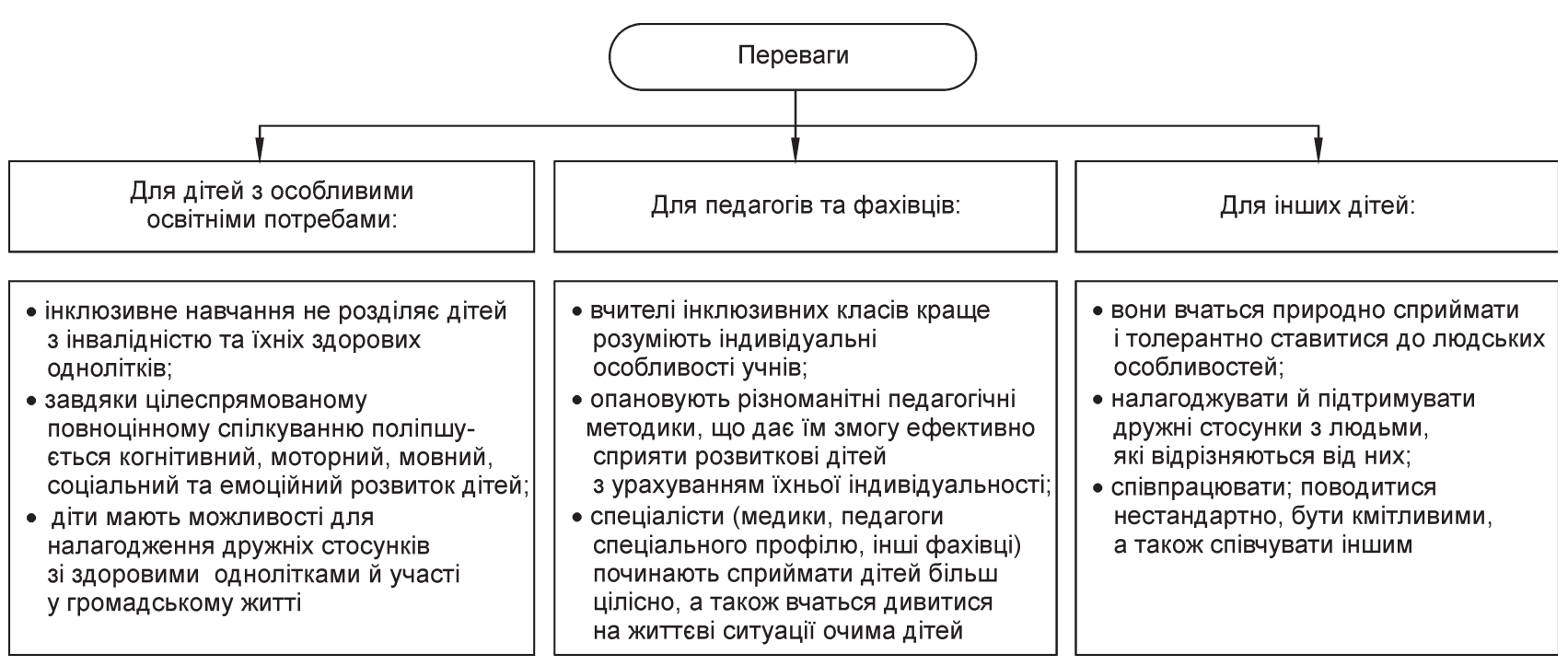

Рисунок 2 - Основні переваги інклюзивного навчання для різних груп населення

У нашій країні інтеграційні процеси людей 3 інвалідністю розпочалися $з$ 1990-х років. У 2001 р. Міністерство освіти і науки України, Інститут спеціальної педагогіки Національної академії педагогічних наук України та Всеукраїнський фонд «Крок за кроком» започаткували науковопедагогічний експеримент «Соціальна адаптація та інтеграція в суспільство дітей 3 особливостями психофізичного розвитку шляхом організації ïx навчання у загальноосвітніх закладах», основною метою якого була розробка й реалізація механізму інтеграції дітей з інвалідністю в загальноосвітні навчальні заклади.

У рамках програми «Інклюзивна освіта» фондом «Крок за кроком» було впроваджено проекти «Реалізація прав людини через рівний доступ до якісної освіти» (2001-2002рр.), «Змінимо світ для дітей з особливими потребами - кроки до партнерства» $(2002$ р.), «Адвокатство батьків - обстоювання права на інклюзивну освіту для дітей $з$ особливими потребами» (2003р.), «Розвиток модельних центрів інклюзивної освіти для дітей з особливими потребами» (2003-2005 рр.), «Створення ресурсних центрів інклюзивної освіти для батьків дітей з особливими потребами» (20052007 рр.), «Впровадження інклюзивної освіти в Україні» (2007р.) [31].

Значний внесок у справу пропаганди інклюзивної освіти зроблено українсько-канадським проектом «Інклюзивна освіта для дітей з особливими освітніми потребами в Україні» (2008-2013 рр.), який здійснювався за підтримки Канадської агенції з міжнародного розвитку. Головним досягненням проекту стало саме донесення до громадськості переваг інклюзивного навчання (рис. 2).

Механізм впровадження інклюзивної освіти забезпечується рядом нормативно-правових документів. Законодавство України про загальну середню освіту базується на Конституції України і складається із Закону України «Про освіту» [7], Закону України «Про загальну середню освіту» [6], інших нормативно-правових актів і міжнародних договорів України, згода на обов'язковість яких надана Верховною Радою України.

Конституція України гарантує право кожного громадянина на доступність до якісної освіти. Це повною мірою повинно стосуватися й дітей з особливими освітніми потребами, до яких належать діти, що мають різні нозологічні вади.

Загалом, інклюзивна форма навчання дає змогу дітям із особливими освітніми потребами навчатися спільно зі своїми здоровими однолітками, що ефективно впливає на рівень їхньої соціалізації.

Головними критеріями дотримання міжнародних норм і вимог національного законодавства щодо реалізації права громадян на отримання освіти мають бути якість і доступність освіти для кожного.

Питання освіти дітей 3 особливими освітніми потребами регулюється також законодавством, зокрема, Законом України «Про основи соціальної захищеності інвалідів в Україні» [8], «Про реабілітацію інвалідів в Україні» [12], нормативними документами у цій сфері та міжнародними договорами з питань прав осіб з інвалідністю.

На сьогодні правове регулювання питань інтегрованої та інклюзивної освіти знаходиться у стані активної розробки та впровадження (табл. 1).

Крім того, відповідні положення щодо впровадження інклюзивного навчання містяться в Законах України «Про освіту» [7], «Про дошкільну освіту» [5], «Про загальну середню освіту» [6], «Про позашкільну освіту» [10], «Про професійнотехнічну освіту» [11], «Про вищу освіту» [4]. Відповідні положення також внесено до законів України «Про охорону дитинства» [9], «Про основи соціальної захищеності осіб з інвалідністю в Україні» [8] та «Про фізичну культуру і спорт» [13] (табл. 2). Отже, можна стверджувати, що в Укра- 
Таблиця 1 - Основні нормативні документи, що визначають права дітей з інвалідністю на інклюзивну освіту

\begin{tabular}{|c|c|}
\hline Дата & Документ \\
\hline 17.04.2002 p. & Указ Президента України № 347/2002 «Про Національну доктрину розвитку освіти» [34] \\
\hline 23.04.2003 p. & $\begin{array}{l}\text { Постанова Кабінету Міністрів України № } 585 \text { «Про встановлення строку навчання у загальноосвітніх на- } \\
\text { вчальних закладах для дітей, які потребують корекції фізичного та (або) розумового розвитку» [26] }\end{array}$ \\
\hline 05.07.2004 p. & $\begin{array}{l}\text { Постанова Кабінету Міністрів України № } 848 \text { «Про затвердження Державного стандарту початкової за- } \\
\text { гальної освіти дітей, які потребують корекції фізичного та(або) розумового розвитку» [28] }\end{array}$ \\
\hline 20.12.2002 p. & $\begin{array}{l}\text { Наказ Міністерства освіти і науки України № 732: «Про затвердження положення про індивідуальну фор- } \\
\text { му навчання в загальноосвітніх навчальних закладах» [32] }\end{array}$ \\
\hline $02.12 .2005 \mathrm{p}$. & $\begin{array}{l}\text { Наказ Міністерства освіти і науки України № 691: «Про створення умов щодо забезпечення права на } \\
\text { освіту осіб з інвалідністю» [41] }\end{array}$ \\
\hline $27.11 .2007 \mathrm{p}$. & $\begin{array}{l}\text { Наказ Міністерства освіти і науки України № 1041: «Про забезпечення прав дітей-інвалідів та дітей, які } \\
\text { потребують корекції фізичного та (або) розумового розвитку» [27] }\end{array}$ \\
\hline $01.10 .2010 \mathrm{p}$. & «Концепція розвитку інклюзивної освіти», затверджена Міністерством освіти і науки України, № 912 [30] \\
\hline 15.08.2011 p. & $\begin{array}{l}\text { «Порядок організації інклюзивного навчання в загальноосвітніх навчальних закладах», затверджений Ка- } \\
\text { бінетом Міністрів України, № } 872 \text { [33] }\end{array}$ \\
\hline 18.05.2012 p. & $\begin{array}{l}\text { Лист Міністерства освіти і науки України № 1/9-384 «Про організацію інклюзивного навчання у загаль- } \\
\text { ноосвітніх навчальних закладах» [38] }\end{array}$ \\
\hline $01.03 .2013 \mathrm{p}$. & $\begin{array}{l}\text { Рішення колегії Міністерства освіти і науки, молоді та спорту країни, протокол № 2/3-2 «Про впрова- } \\
\text { дження інклюзивного навчання в загальноосвітніх навчальних закладах: реалії та перспективи» [25] }\end{array}$ \\
\hline $25.06 .2013 \mathrm{p}$. & $\begin{array}{l}\text { Указ Президента України № 344/2013 «Про Національну стратегію розвитку освіти в Україні на період } \\
\text { до } 2021 \text { року» [35] }\end{array}$ \\
\hline 14.06.2013 p. & $\begin{array}{l}\text { Наказ МОН України № } 768 \text { «План заходів щодо забезпечення права на освіту дітей з особливими освіт- } \\
\text { німи потребами, у тому числі дітей-інвалідів» [20] }\end{array}$ \\
\hline 23.07.2013 p. & $\begin{array}{l}\text { Наказ МОН України № } 1034 \text { «Про затвердження заходів щодо впровадження інклюзивного навчання в } \\
\text { дошкільних та загальноосвітніх навчальних закладах на період до } 2015 \text { року» [29] }\end{array}$ \\
\hline 08.08.2013 p. & $\begin{array}{l}\text { Лист МОН України № 1/9-533 «Про організаційно-методичні засади забезпечення права на освіту дітям } \\
\text { з особливими освітніми потребами» [36] }\end{array}$ \\
\hline 25.03.2014 p. & $\begin{array}{l}\text { Постанова Верховної Ради України № 1158-VII «Про проведення парламентських слухань на тему: } \\
\text { «Освіта, охорона здоров'я та соціальне забезпечення дітей з порушеннями психофізичного розвитку: } \\
\text { проблеми та шляхи їх вирішення» [39] }\end{array}$ \\
\hline 13.01.2015 p. & $\begin{array}{l}\text { Постанова Верховної Ради України № 96-VIII «Про Рекомендації парламентських слухань на тему: «Осві- } \\
\text { та, охорона здоров’я та соціальне забезпечення дітей з порушеннями психофізичного розвитку: про- } \\
\text { блеми та шляхи їх вирішення» [40] }\end{array}$ \\
\hline 05.07.2017 p. & $\begin{array}{l}\text { Закон України № 2053-VIII Про внесення змін до Закону України «Про освіту» щодо особливостей до- } \\
\text { ступу осіб з особливими освітніми потребами до освітніх послуг [23] }\end{array}$ \\
\hline 10.11.2017 p. & $\begin{array}{l}\text { Наказ МОН України № } 4706 \text { «Про внесення змін до наказу Міністерства молоді та спорту України від } \\
17 \text { січня } 2015 \text { року N } 67 \text { «Про організацію навчально-тренувальної роботи дитячо-юнацьких спортивних } \\
\text { шкіл» [24] }\end{array}$ \\
\hline 13.12.2017 p. & $\begin{array}{l}\text { Розпорядження Кабінету Міністрів України № 903-р Про затвердження плану заходів на 2017-2029 роки } \\
\text { із запровадження Концепції реалізації державної політики у сфері реформування загальної середньої } \\
\text { освіти «Нова українська школа» [31] }\end{array}$ \\
\hline $16.01 .2018 \mathrm{p}$. & Закон України № 2249-VIII «Про внесення змін до деяких законодавчих актів України» [22] \\
\hline $06.09 .2018 \mathrm{p}$. & $\begin{array}{l}\text { Закон України № 2541-VIII «Про внесення змін до деяких законів України щодо доступу осіб з особливи- } \\
\text { ми освітніми потребами до освітніх послуг» [23] }\end{array}$ \\
\hline 05.08.2019 p. & $\begin{array}{l}\text { Лист МОН № 1/9-498 щодо методичних рекомендацій щодо навчання дітей з особливими освітніми по- } \\
\text { требами в 2019/2020 н.р. [45] }\end{array}$ \\
\hline $21.08 .2019 \mathrm{p}$. & $\begin{array}{l}\text { Постанова Кабінету Міністрів України № } 779 \text { «Про організацію інклюзивного навчання в закладах поза- } \\
\text { шкільної освіти» [37] }\end{array}$ \\
\hline
\end{tabular}

їні на законодавчому рівні закріплено захист права дітей з особливими освітніми потребами на здобуття знань у дошкільних, загальноосвітніх, позашкільних, професійно-технічних і вищих навчальних закладах.
Одним із перших важливих кроків, спрямованих на вирішення питання освіти дітей з інвалідністю, став Указ Президента України від 17.04.2002 р. «Про Національну доктрину розвитку освіти» [34]. На розвиток норм і положень статтей 19, 
20 Закону України «Про освіту» поставлено конкретні завдання із забезпечення рівного доступу та державної підтримки дітей та молоді з інвалідністю, зокрема, створення належних умов для здобуття ними безплатної освіти в державних i комунальних навчальних закладах; забезпечення варіативності здобуття якісної базової чи повної середньої освіти із урахуванням здібностей та індивідуальних властивостей дітей, спрямованої на їх інтеграцію в соціально-економічне середовище; створення системи допомоги батькам у навчанні та вихованні дітей $з$ інвалідністю.
У наступні роки видано ряд постанов Кабінету Міністрів України про створення умов для забезпечення прав на освіту осіб з інвалідністю [26, $28,31,33]$.

Проте нормативно-правова база 2002-2007 pp. повністю не вирішувала цієї проблеми і потребувала запровадження необхідних положень на законодавчому рівні. Хоча чинним на той час законодавством і була передбачена можливість здобуття освіти особами 3 інвалідністю [7, 8], але ті чинні норми не забезпечували правових засад для комплексного вирішення проблеми.

Таблиця 2 - Впровадження положень про інклюзивне навчання в закони України, що регламентують освітній процес

\begin{tabular}{|c|c|c|}
\hline Закон України & Остання редакція & Статті, що стосуються інклюзивної освіти \\
\hline ЗУ «Про освіту» [7] & 05.09.2017 p. & $\begin{array}{l}\text { Стаття 19. Освіта осіб з особливими освітніми потребами. } \\
\text { Стаття 20. Їнклюзивне навчання. }\end{array}$ \\
\hline ЗУ «Про дошкільну освіту» [5] & 28.09.2017 p. & $\begin{array}{l}\text { Стаття 12. Типи закладів дошкільної освіти. } \\
\text { Стаття 33. Соціальний захист дітей дошкільного віку. }\end{array}$ \\
\hline $\begin{array}{l}\text { ЗУ «Про загальну середню осві- } \\
\text { ту» [6] }\end{array}$ & 28.09.2017 p. & $\begin{array}{l}\text { Стаття 9. Типи закладів освіти, що забезпечують здобуття загальної } \\
\text { середньої освіти. } \\
\text { Стаття 21. Соціальний захист учнів (вихованців). }\end{array}$ \\
\hline $\begin{array}{l}\text { ЗУ «Про позашкільну освіту» } \\
\text { [10] }\end{array}$ & 16.07.2019 p. & $\begin{array}{l}\text { Стаття 6. Здобуття позашкільної освіти. } \\
\text { Стаття 8. Основні завдання позашкільної освіти. } \\
\text { Стаття 9. Основні засади державної політики у сфері позашкільної } \\
\text { освіти. } \\
\text { Стаття 10. Органи управління позашкільною освітою. Державний на- } \\
\text { гляд (контроль) у сфері позашкільної освіти. } \\
\text { Стаття 18. Форми організації позашкільної освіти. } \\
\text { Стаття 20. Права, обов'язки та соціальний захист вихованців, учнів і } \\
\text { слухачів закладу позашкільної освіти. }\end{array}$ \\
\hline $\begin{array}{l}\text { ЗУ «Про професійно-технічну } \\
\text { освіту» [11] }\end{array}$ & 05.03.2017 p. & $\begin{array}{l}\text { Стаття 5. Право на здобуття професійно-технічної освіти. } \\
\text { Стаття 41. Учні, слухачі професійно-технічних навчальних закладів, } \\
\text { яким забезпечується особливий соціальний захист. } \\
\text { Стаття 42. Соціальний захист інвалідів. }\end{array}$ \\
\hline ЗУ «Про вищу освіту» [4] & $01.01 .2018 \mathrm{p}$ & Стаття 4. Право на вищу освіту. \\
\hline ЗУ «Про охорону дитинства» [9] & 20.01.2018 p. & $\begin{array}{l}\text { Стаття 19. Право на освіту. } \\
\text { Стаття 26. Захист прав дітей з інвалідністю та дітей з вадами розу- } \\
\text { мового або фізичного розвитку. } \\
\text { Стаття 27. Заклади для дітей з інвалідністю та дітей з вадами розу- } \\
\text { мового або фізичного розвитку. }\end{array}$ \\
\hline $\begin{array}{l}\text { ЗУ «Про основи соціальної захи- } \\
\text { щеності інвалідів в Україні» [8] }\end{array}$ & 20.01.2018 p. & $\begin{array}{l}\text { Стаття 21. Держава гарантує особам з інвалідністю дошкільне вихо- } \\
\text { вання, здобуття освіти на рівні, що відповідає ї здібностям і можли- } \\
\text { востям. } \\
\text { Стаття 22. Для реалізації права на вищу освіту та професійно- } \\
\text { технічну освіту особами з інвалідністю вищі навчальні заклади та } \\
\text { професійно-технічні заклади створюють їм необхідні умови для здо- } \\
\text { буття відповідної освіти. }\end{array}$ \\
\hline $\begin{array}{l}\text { ЗУ «Про фізичну культуру і } \\
\text { спорт» [13] }\end{array}$ & 16.07.2019 p. & $\begin{array}{l}\text { Стаття 1. Основні терміни та їх визначення. } \\
\text { Стаття 4. Засади державної політики у сфері фізичної культури і } \\
\text { спорту. } \\
\text { Стаття 7. Показники стану розвитку фізичної культури і спорту. } \\
\text { Стаття 17. Центри фізичної культури і спорту осіб з інвалідністю. } \\
\text { Стаття 20. Спортивні федерації. } \\
\text { Стаття 24. Суб’єкти паралімпійського і дефлімпійського руху в Укра- } \\
\text { їні. } \\
\text { Стаття 26. Фізична культура у сфері освіти. } \\
\text { Стаття 31. Фізкультурно-оздоровча діяльність і фізкультурно- } \\
\text { спортивна реабілітація осіб з інвалідністю. } \\
\text { Стаття 48. Матеріально-технічне забезпечення сфери фізичної куль- } \\
\text { тури і спорту. } \\
\text { Стаття 49. Кадрове забезпечення сфери фізичної культури і спорту. }\end{array}$ \\
\hline
\end{tabular}


Законом України «Про загальну середню освіту» від 6 липня 2010 р. [6] було внесено зміни до частини третьої статті 9 Закону, де передбачено, що «загальноосвітні навчальні заклади можуть створювати у своєму складі класи (групи) 3 вечірньою (заочною), дистанційною формами навчання, класи (групи) з поглибленим вивченням окремих предметів, спеціальні та інклюзивні класи для навчання дітей з особливими освітніми потребами» [6].

У такий спосіб на законодавчому рівні було закріплено право на інклюзію в системі загальної середньої освіти, що давало додатковий стимул для iï успішного впровадження.

У жовтні 2010 р. Міністерство освіти і науки України затвердило «Концепцію розвитку інклюзивної освіти» [30], яка передбачає необхідне навчально-методичне забезпечення освітнього процесу в умовах інклюзивного навчання та здійснення відповідних інституційних змін.

На виконання поставлених завдань у серпні 2011 р. Кабінет Міністрів України затвердив «Порядок організації інклюзивного навчання в загальноосвітніх навчальних закладах» [33], а Міністерство освіти і науки України для реалізації норм і положень цієї постанови видало ряд відповідних нормативних актів. Вони визначають порядок формування інклюзивних класів та їхню наповнюваність, передбачають корекційну спрямованість навчально-виховного процесу, організацію психологічного й соціального супроводу, запровадження посади вихователя (асистента вчителя), який забезпечує соціально-педагогічний супровід дитини $з$ особливими освітніми потребами у загальноосвітніх навчальних закладах інклюзивного навчання [20, 25, 38].

Законодавче забезпечення інклюзивної форми навчання уможливило початок її успішного впровадження в Україні. Станом на 1 березня 2011 р. в Україні було створено близько 536 спеціальних класів у загальноосвітніх школах. Тоді ж Міністерство освіти і науки України відзвітувало, що вже майже 130 тис. дітей 3 інвалідністю охоплені інклюзивною освітою [14].

3 липня 2016 р. до впровадження інклюзивної освіти долучилася Марина Порошенко. Під їі кураторством Фонд Порошенка почав реалізацію ряду регіональних проектів із впровадження інклюзивної освіти в регіонах України, спрямованих на основні пріоритети розвитку інклюзивної освіти:

- врегулювання юридично-правових норм реалізації права на освіту для всіх дітей без винятку;

- забезпечення державного фінансування додаткових послуг для дітей 3 особливими освітніми потребами;

- створення інклюзивних ресурсних центрів, які будуть займатися і супроводжувати дітей 3 особливими освітніми потребами;
- адаптація освітніх матеріалів, підготовка педагогів, проведення інформаційної та роз'яснювальної роботи 3 популяризації інклюзивної освіти в Україні [43].

В липні 2017 р. Президент України Петро Порошенко підписав Закон України № 2053-VIII Про внесення змін до Закону України «Про освіту» щодо особливостей доступу осіб з особливими освітніми потребами до освітніх послуг [23]. Цим законом визначено право на освіту осіб з особливими освітніми потребами та надано їм можливість здобувати освіту в усіх навчальних закладах, в тому числі безкоштовно в державних і комунальних навчальних закладах, незалежно від «встановлення інвалідності». Також передбачена можливість введення дистанційної та індивідуальної форм навчання; визначено поняття «особа з особливими освітніми потребами», «інклюзивне навчання»; надана можливість особам 3 особливими освітніми потребами отримувати психологопедагогічну та корекційно-розвиваючу допомогу, створювати для таких осіб інклюзивні та спеціальні групи (класи) в загальноосвітніх навчальних закладах.

Базовим документом для створення інклюзивної освіти в Україні є концепція «Нової української школи» [31], яку затвердила Національна Рада Реформ у квітні 2017 р. За словами їі ініціатора, міністра освіти Лілії Гриневич, концепція прописує реформування освіти до 2029 р.

У 2017 р. Наказом Міністерства молоді та спорту № 4607 було внесено зміни до Наказу № 67 «Про організацію навчально-тренувальної роботи дитячо-юнацьких спортивних шкіл», які передбачали зміни мінімального віку вихованців, які зараховуються до груп відділень з видів спорту осіб 3 інвалідністю дитячо-юнацьких спортивних шкіл для осіб з інвалідністю, спеціалізованих дитячоюнацьких спортивних шкіл для осіб з інвалідністю паралімпійського та дефлімпійського резерву, дитячо-юнацьких спортивних шкіл, де є відділення (спортсмени) з видів спорту для осіб з інвалідністю [18, 24].

16 січня 2018 р. Президент України Петро Порошенко підписав Закон № 2249-VIII «Про внесення змін до деяких законодавчих актів України». Цим документом вносяться зміни до 37 Законів України, в положеннях яких слова «інвалід», «дитина-інвалід» та «інвалід війни» замінено відповідно словами «особа 3 інвалідністю», «дитина 3 інвалідністю» та «особа $з$ інвалідністю внаслідок війни» [23].

У вересні 2018 р. було підписано Закон України «Про внесення змін до деяких законів України щодо доступу осіб з особливими освітніми потребами до освітніх послуг» [21]. Цим Законом було внесено зміни до $3 У$ «Про позашкільну освіту». Відповідно, діти з особливими освітніми потребами отримали можливість займатися в позашкільних групах (гуртках) фізкультурно-спортивного 
або спортивного напряму. Даний напрям дозволяє заняття фізичною культурою і спортом, розвиток фізичних здібностей вихованців (незалежно від рівня їхнього здоров'я), повноцінне оздоровлення, набуття навичок здорового способу життя. Крім фізкультурно-спортивного напряму, діти 3 особливими освітніми потребами можуть обрати соціально-реабілітаційний напрям. Це допоможе соціалізуватися особам 3 інвалідністю в суспільстві, самореалізуватися та підготуватися до активної професійної та громадської діяльності.

3 розвитком нормативно-правової бази інклюзивна освіта активно впроваджується на рівні вищої школи, а саме - розробляється науково-методичне забезпечення сфери інклюзивної освіти. У 13 вищих навчальних закладах країни запроваджено курс корекційної освіти. У системі Інститутів післядипломної педагогічної освіти запроваджено навчальні програми: «Вступ до інклюзивної освіти», «Диференційоване викладання в інклюзивному класі», а також навчальну програму й навчально-методичний посібник «Професійне співробітництво в інклюзивному навчальному закладі»; навчальну програму та навчально-методичний посібник для педагогічних університетів «Основи інклюзивної освіти [17].

Проте, незважаючи на пожвавлення роботи із запровадження інклюзивної освіти й певні успіхи на цьому шляху, є чимало перешкод для iї успішного розвитку. Головним негативним чинником $є$ брак фінансування інклюзивної освіти. Окремого фінансування освіти для дітей з особливими освітніми потребами немає і його не закладено в бюджет. Унаслідок цього постає проблема недостатнього матеріально-технічного та кадрового забезпечення загальноосвітніх навчальних закладів (відсутність спеціального допоміжного навчального обладнання, спеціально розроблених навчальних методик та програм інклюзивного навчання, недостатня чисельність спеціально підготовлених фахівців для роботи з особами з інвалідністю). На сьогодні, лише $20 \%$ загальноосвітніх навчальних закладів є повністю, а $45 \%$ - частково доступними для дітей з інвалідністю. Тільки 32 \% професійно-навчальних закладів обладнані пандусами, звуковою сигналізацією та інформаційними табличками [14].

Однією з основних проблем у сфері освіти дітей з особливими освітніми потребами є також відсутність послідовності в наданні освітніх та реабілітаційних послуг на всіх рівнях освітнього процесу з обов'язковою психолого-педагогічною, медичною та фізичною реабілітацією. Сьогодні відсутня і класифікація психофізичних порушень, що визначала б, з якими порушеннями діти можуть приходити до закладів освіти [19].

Окрім об'єктивних чинників, інтегрування дітей 3 інвалідністю у суспільство ускладнює непідготовленість до їх сприйняття. Спостерігаються непоодинокі випадки, коли дітям 3 інвалідністю відмовляють у прийнятті до навчального закла- ду через упереджене до них ставлення. Іноді до дітей 3 особливими освітніми потребами виявляють надмірну турботливість, що відповідно до європейських стандартів не є рівністю умов. Водночас залишається низьким рівень поінформованості суспільства про інклюзивну освіту.

Проте, слід зазначити, що протягом останнього часу в Україні значно зріс інтерес до спільних занять спортом дітей з інвалідністю та дітей, які не мають вад розвитку. На державному рівні відбувається ефективне залучення всіх вихованців (учнів/студентів) до навчально-тренувального процесу, у тому числі й осіб з інвалідністю. Велика увага приділяється розвитку адаптивної фізичної культури та адаптивного спорту, що підкріплюється відкриттям інклюзивних гуртків позашкільного профілю, спортивних секцій зі «змішаними» групами вихованців.

Дискусія. Підсумовуючи сказане, можна виокремити основні умови, які є визначальними в успішності інклюзивних процесів:

- стійка соціальна державна політика, зорієнтована на інтегрування всіх без винятку членів суспільства;

- проведення корекційно-розвиваючих заходів для дітей з інвалідністю;

- соціальна підтримка і допомога сім'ям дітей 3 інвалідністю;

- обмеження практики навчання дітей з особливими освітніми потребами в умовах сегрегації;

- розвиток законодавчої бази інклюзивної освіти осіб з інвалідністю;

- створення i розширення системи освітньої i професійно-трудової підготовки осіб з інвалідністю в державні і недержавні структури;

- формування толерантного ставлення до людей з інвалідністю.

Отже, перспективи розвитку інклюзивної освіти вимагають узгоджених і невідкладних дій 3 боку керівництва держави, Міністерства освіти і науки, Міністерства охорони здоров'я, Міністерства праці і соціальної політики, Міністерства молоді та спорту, а також громадських організацій та всього українського суспільства.

\section{Висновки:}

1. У розвинених країнах Свропи інклюзивне навчання в освітніх закладах різного типу відображає одну з головних демократичних ідей - усі діти є цінними й активними членами суспільства. Інклюзія означає розкриття кожного учня за допомогою освітньої програми, яка є досить складною, але відповідає його здібностям. Вона враховує потреби, а також спеціальні умови та підтримку, що забезпечується медико-соціальним та психологопедагогічним супроводом. Інклюзивне навчання в Свропі орієнтоване на формування спрямованості дітей з інвалідністю до повноцінного життя, до 
усвідомлення власної спроможності, підвищення якості власного буття.

2. Аналіз питання державної політики у сфеpi запровадження інклюзивної освіти та їі сучасного стану дозволяє стверджувати, що останніми роками в цьому напрямі досягнуто певних успіхів. Зокрема, на законодавчому рівні закріплено право створювати в закладах середньої освіти спеціальні та інклюзивні класи для навчання дітей з особливими освітніми потребами; ухвалено ряд нормативно-правових актів, спрямованих на реалізацію норм і положень законодавства; активізовано розробку науково-методичного забезпечення інклюзивної освіти; удосконалено сферу фізичної культури і спорту для виховання осіб з інвалідністю; змінено мінімальний вік вихованців з видів спорту для осіб з інвалідністю тощо.

3. Для успішного розвитку системи інклюзивного навчання в освітніх закладах різного типу необхідно здійснити такі заходи: продовжувати законодавче оформлення цієї системи навчання не лише в закладах середньої освіти, а й в закладах дошкільної, професійно-технічної та вищої освіти, закладах позашкільної освіти спортивного профілю; приділяти особливу увагу додатковій освітянській підготовці вчителів та вихователів, які працюють 3 дітьми 3 інвалідністю, підготовці тренерських кадрів для роботи у дитячо-юнацьких спортивних школах для осіб 3 інвалідністю, спортивних клубах; внести фінансування інклюзивної освіти до переліку захищених статей Закону України «Про Державний бюджет України»; запровадити спеціальні експертизи відповідності законів України про освіту положенням Конвенції ООН «Про права осіб з інвалідністю» тощо.

Конфлікт інтересів. Автори заявляють, що відсутній будь-який конфлікт інтересів.

\section{Література}

1. Адирхаєв СГ. Сучасна технологія фрізичного виховання студентів з обмеженими можливостями здоров'я в умовах інклюзивної освіти. Педагогіка, психологія та медико-біологічні проблеми фрізичного виховання і спорту. 2016.1:4-12.

2. Барановська ЛВ, Барановський ММ. Концептуальний аспект навчання дорослих в системі вищої освіти України. Вісник Національного авіаційного університету. 2014.5 (1):14-19.

3. Борисова ОВ, Когут ІО, Маринич ВЛ, Чебанова КВ. Проблеми та перспективи розвитку інклюзивної освіти в Україні. Фізична активність і якість життя людини. 2018:56.

4. Верховна Рада України. Закон України «Про вищу освіту» (станом на 16 січня 2020 року). Київ: Офіційний вісник України; 2020. 88 с.

5. Верховна Рада України. Закон України «Про дошкільну освіту» (станом на 16 липня 2019 року). Київ: Офріційний вісник України; 2019. 27 с.

6. Верховна Рада України. Закон України «Про загальну середню освіту» (станом на 9 серпня 2019 року). Київ: Офріційний вісник України; 2019. 27 с.

7. Верховна Рада України. Закон України «Про освіту» (станом на 16 січня 2020 року). Київ: Офріційний вісник України; 2020. 104 с.

8. Верховна Рада України. Закон України «Про основи соціальної захищеності осіб з інвалідністю в Україні» (станом на 13 лютого 2020 року). Київ: Офіційний вісник України; 2020. 24 с.

9. Верховна Рада України. Закон України «Про охорону дитинства» (станом на 9 серпня 2019 року). Київ: Офіційний вісник України; 2019. 25 с.

10. Верховна Рада України. Закон України «Про позашкільну освіту» (станом на 16 січня 2020 року). Київ: Офріційний вісник України; 2020. 24 с.

11. Верховна Рада України. Закон України «Про професійно-технічну освіту» (станом на 1 січня 2019 року). Київ: Офріційний вісник України; 2019. 31 с.

12. Верховна Рада України. Закон України «Про реабілітацію осіб з інвалідністю в Україні» (станом на 1 січня 2020 року). Київ: Офріційний вісник України; 2020. 30 с.

13. Верховна Рада України. Закон України «Про фрізичну культуру і спорт» (станом на 16 липня 2019 року). Київ: Офріційний вісник України; 2019. 34 с.

14. Державна служба статистики України. Показник інклюзії в Україні [Інтернет]. Київ: ДССУ ; 2018 [оновлено 2018 Січ. 10; цитовано 2019 Гру 20]. Доступно: http://www.ukrstat.gov.ua/

15. Когут ІО, Маринич ВЛ, Чебанова КВ. Загальні положення інклюзивної освіти як сучасного соціальнопедагогічного феномену та підґрунтя для соціальної інтеграції спортсменів з інвалідністю. Теорія і методика фрізичного виховання і спорту. 2017; (2): 14-19.

16. Когут IO. Соціально-гуманістичні засади розвитку адаптивної фрізичної культури в Україні (на матеріалі адаптивного спорту) [монографія]. Львів: СПОЛОМ; 2015. 284 с.

17. Колупаєва АА, Таранченко ОМ, Білозерська IО та ін. Основи інклюзивної освіти: навч.-метод. посіб. Київ: А. С. К; 2012. 308 с.

18. Навчальна програма з позашкільної освіти фрізкультурно-спортивного напряму «Карате - тренуємося разом» (авт. Когут ІО, Маринич ВЛ, Чебанова КВ.) «Схвалено для використання в позашкільних навчальних закладах» (протокол засідання науково-методичної комісії з позашкільної освіти Науково-методичної ради 3 питань освіти МОН України від 26.06 2019 № 2; лист ІМЗО від 08.07.2019 № 22.1/12-Г-588). 
19. Перфільєва МВ. Інклюзивна освіта - крок назустріч рівноправності. Тези доповідей VII Всеукр. науковопракт. конф.; 2012 Квіт. 27; Хмельницький. Хмельницький інститут соціальних технологій Університету «Україна».; 2012. 338 с.

20. План заходів щодо забезпечення права на освіту дітей з особливими освітніми потребами, у тому числі дітей-інвалідів: Наказ Міністерства освіти і науки України № 768; 2013 Черв. 14. МОН України. 2014.

21. Про внесення змін до деяких законів України щодо доступу осіб з особливими освітніми потребами до освітніх послуг: Закон України № 2541-VIII; 2018 Вер. 6. Офіційний вісник України; 2018. 11 с.

22. Про внесення змін до деяких законодавчих актів України: Закон України № 2249-VIII; 2018 Груд. 19. Офріційний вісник України; 2018. 12 с.

23. Про внесення змін до Закону України «Про освіту» щодо особливостей доступу осіб з особливими освітніми потребами до освітніх послуг: Закон України № 2053-VIII; 2017 Вер. 28. Офріційний вісник України; 2017. 3 C.

24. Про внесення змін до наказу Міністерства молоді та спорту України № 67 «Про організацію навчальнотренувальної роботи дитячо-юнацьких спортивних шкіл»; 2015 Січ. 17. Наказ МОН України № 4706. 2015.

25. Про впровадження інклюзивного навчання в загальноосвітніх навчальних закладах: реалії та перспективи: Рішення колегії Міністерства освіти і науки, молоді та спорту країни, протокол № 2/3-2; 2013 Бер. 01. МОНмолодьспорт. 2013.

26. Про встановлення строку навчання у загальноосвітніх навчальних закладах для дітей, які потребують корекції фрізичного та (або) розумового розвитку: Постанова Кабінету Міністрів України № 585; 2003 Квіт. 23. КМУ. 2003.

27. Про забезпечення прав дітей-інвалідів та дітей, які потребують корекції фізичного та (або) розумового розвитку: Наказ Міністерства освіти і науки України № 1041; 2007 Листоп. 27. Ліга: закон. 2007.

28. Про затвердження Державного стандарту початкової загальної освіти дітей, які потребують корекції фрізичного та(або) розумового розвитку: Постанова Кабінету Міністрів України № 848; 2013 Серп. 21. КМУ. 2013.

29. Про затвердження заходів щодо впровадження інклюзивного навчання в дошкільних та загальноосвітніх навчальних закладах на період до 2015 року: Наказ Міністерства освіти і науки України № $1034 ; 2013$ Серп. 23. МОН України. 2013.

30. Про затвердження концепції розвитку інклюзивного навчання: Наказ Міністерства освіти і науки України № 912; 2010 Жовт. 01. МОН України. 2010.

31. Про затвердження плану заходів на 2017-2029 роки із запровадження Концепції реалізації державної політики у сфері реформування загальної середньої освіти «Нова українська школа»; Розпорядження Кабінету Міністрів України № 903-р; 2019 Квіт. 17. КМУ. 2019.

32. Про затвердження положення про індивідуальну форму навчання в загальноосвітніх навчальних закладах: Наказ Міністерства освіти і науки України № 732; 2019 Серп. 20; МОН України. 2020.

33. Про затвердження порядку організації інклюзивного навчання в загальноосвітніх навчальних закладах: Постанова Кабінету Міністрів України № 872; 2011 Серп. 15. КМУ. 2011.

34. Про Національну доктрину розвитку освіти: Указ Президента України № 347/2002; 2002 Квіт. 17. Офріційний вісник Президента України. 2002.

35. Про Національну стратегію розвитку освіти в Україні на період до 2021 року: Указ Президента України № 344/2013; 2013 Черв. 25. Офіційний вісник Президента України. 2013.

36. Про організаційно-методичні засади забезпечення права на освіту дітям з особливими освітніми потребами: Лист Міністерства освіти і науки України № 1/9-533; 2016 Лип. 12. МОН України. 2016

37. Про організацію інклюзивного навчання в закладах позашкільної освіти: Постанова Кабінету Міністрів України № 779; 2019 Серп. 21. КМУ. 2019.

38. Про організацію інклюзивного навчання у загальноосвітніх навчальних закладах: Лист Міністерства освіти і науки України № 1/9-384; 2012 Трав. 5. МОН України. 2012.

39. Про проведення парламентських слухань на тему: «Освіта, охорона здоров'я та соціальне забезпечення дітей з порушеннями психофізичного розвитку: проблеми та шляхи їх вирішення: Постанова Верховної Ради України № 1158-VII; 2014 Бер. 25. ВВР № 23. 2014.

40. Про Рекомендації парламентських слухань на тему: «Освіта, охорона здоров'я та соціальне забезпечення дітей з порушеннями психофрізичного розвитку: проблеми та шляхи їх вирішення: Постанова Верховної Ради України № 96-VIII; 2015 Січ. 01. ВBP № 10. 2015.

41. Про створення умов щодо забезпечення права на освіту осіб з інвалідністю: Наказ Міністерства освіти і науки України № 691; 2005 Груд. 02; МОН України. 2005.

42. Чайковський Мє. Теорія і практика соціально-педагогічної роботи з молоддю з особливими потребами в умовах інклюзивного освітнього простору [дисертація]. Старобільськ: «Луганський національний університет імені Тараса Шевченка»; 2016. 570 с.

43. Черніченко ЛА. Інклюзивна освіта як сучасна освітня інновація. Молодий вчений. 2016; 39 (12): 537 - 541.

44. Шевців ЗМ. Вплив законодавчої бази інклюзивної освіти на підготовку майбутнього вчителя до роботи в інклюзивному середовищі загальноосвітнього навчального закладу. Народна освіта. 2017. 2: 10-16.

45. Щодо методичних рекомендацій щодо навчання дітей з особливими освітніми потребами в 2019/2020 н. р.: Лист Міністерства освіти і науки України № 1/9-498; 2019 Серп. 5. МОН України. 2019.

46. Armstrong F, Armstrong D, Barton L. Inclusive education: policy, contexts and comparative perspectives. Routledge. 2016: 176 p.

47. O'Hanlon C. Inclusive education in Europe. Routledge. 2017: 164 p.

48. Raymond E. B. Learners with mild disabilities: A characteristics approach. Pearson. 2016: 317 p. 


\section{Literature:}

1. Adyrkhaev SH. Modern technology of physical education of students with disabilities in an inclusive education. Pedahohika, psykholohiia ta medyko-biolohichni problem fizychnoho vykhovannia i sportu. 2016.1:4-12.

2. Baranovska LV, Baranovskyi MM. Conceptual aspect of adult learning in the system of higher education in Ukraine. Visnyk Natsionalnoho aviatsiynoho universytetu. 2014.5 (1):14-19.

3. Borysova OV, Kohut IO, Marynych VL, Chebanova KV. Problems and prospects for the development of inclusive education in Ukraine. Fizychna aktyvnist i iakist zhyttia liudyny. 2018:56.

4. Verkhovna Rada of Ukraine. Law of Ukraine «On Higher Education» (as of January 16, 2020). Kyiv: Official Herald of Ukraine; 2020. 88 p.

5. Verkhovna Rada of Ukraine. Law of Ukraine «On Preschool Education» (as of July 16, 2019). Kyiv: Official Herald of Ukraine; 2019. 27 p.

6. Verkhovna Rada of Ukraine. Law of Ukraine «On General Secondary Education» (as of August 9, 2019). Kyiv: Official Herald of Ukraine; 2019. 27 p.

7. Verkhovna Rada of Ukraine. Law of Ukraine «On Education» (as of January 16, 2020). Kyiv: Official Herald of Ukraine; 2020. 104 p.

8. Verkhovna Rada of Ukraine. Law of Ukraine «On the basis of social protection of persons with disabilities in Ukraine» (as of February 13, 2020). Kyiv: Official Herald of Ukraine; 2020. 24 p.

9. Verkhovna Rada of Ukraine. Law of Ukraine «On Child Protection» (as of August 9, 2019). Kyiv: Official Herald of Ukraine; 2019. 25 p.

10. Verkhovna Rada of Ukraine. Law of Ukraine «On Extracurricular Education» (as of January 16, 2020). Kyiv: Official Herald of Ukraine; 2020. 24 p.

11. Verkhovna Rada of Ukraine. Law of Ukraine «On Vocational Education» (as of January 1, 2019). Kyiv: Official Herald of Ukraine; 2019. 31 p.

12. Verkhovna Rada of Ukraine. Law of Ukraine «On Rehabilitation of Persons with Disabilities in Ukraine» (as of January 1, 2020). Kyiv: Official Herald of Ukraine; 2020. 30 p.

13. Verkhovna Rada of Ukraine. Law of Ukraine «On Physical Culture and Sports» (as of July 16, 2019). Kyiv: Official Herald of Ukraine; 2019. 34 p.

14. State Statistics Service of Ukraine. Inclusion indicator in Ukraine [Internet]. Kyiv: SSSU; 2018 [updated 2018 Jan. 10; cited 2019 Dec 20]. Available: http://www.ukrstat.gov.ua/

15. Kohut I, Marynych VL., Chebanova KV. General provisions of inclusive education as a modern sociopedagogical phenomenon and the basis for social integration of athletes with disabilities. Teoriia i metodyka fizvykhovannia i sportu. 2017; (2): 14-19.

16. Kohut IO. Socio-humanistic principles of development of adaptive physical culture in Ukraine (on the material of adaptive sports) [monograph]. Lviv: SPOLOM; 2015. 284 p.

17. Kolupaieva AA, Taranchenko OM, Bilozerska 10 et al. Inclusive education fundamentals: teaching guide. Kyiv: A. S. K; 2012. 308 p.

18. Curriculum for extracurricular education in physical culture and sports "Karate - train together» (authors Kohut IO, Marynych VL, Chebanova KV) «Approved for use in out-of-school educational institutions» (minutes of the meeting of Methodical Commission for Extracurricular Education of the Scientific and Methodological Council for Education of the Ministry of Education and Science of Ukraine dated June 26, 2019 № 2;

19. Perfilieva MV. Inclusive education - step to equality. Tezy dopovidei VII Vseukrainskoi naukovo-praktychno konferentsii; 2012 Apr. 27; Khmeknitskyi instytut sotsialnykh tekhnolohii Universytetu «Ukraina».; 2012. 338 p.

20. Action plan to ensure the right to education of children with special educational needs, including children with disabilities: Order of the Ministry of Education and Science of Ukraine № 768; 2013 Jun. 14. MES of Ukraine. 2014.

21. On Amendments to Certain Laws of Ukraine Concerning Access of Persons with Special Educational Needs to Educational Services: Law of Ukraine № 2541-VIII; 2018 Ver. 6. Official Herald of Ukraine; 2018.11 p.

22. On Amendments to Certain Legislative Acts of Ukraine: Law of Ukraine № 2249 - VIII; 2018 Dec. 19. Official Herald of Ukraine;2018. 12 p.

23. On Amendments to the Law of Ukraine "On Education" Regarding the Peculiarities of Access of Persons with Special Educational Needs to Educational Services: Law of Ukraine № 2053-VIII; 2017 Ver. 28. Official Herald of Ukraine; 2017. 3 p.

24. On amendments to the order of the Ministry of Youth and Sports of Ukraine України 67 «On the organization of educational and training work of children's and youth sports schools»; 2015 Jan. 17. Order of the Ministry of Education and Science of Ukraine № 4706. 2015.

25. On the introduction of inclusive education in secondary schools: realities and prospects: Decision of the Board of the Ministry of Education and Science, Youth and Sports of the country, protocol № 2 / 3-2; 2013 Mar. 01. MONmolodsport. 2013

26. On establishing the term of study in general educational institutions for children in need of correction of physical and (or) mental development ": Resolution of the Cabinet of Ministers of Ukraine № 585; 2003 April. 23. KMU.2003.

27. On ensuring the rights of children with disabilities and children in need of correction of physical and (or) mental development: Order of the Ministry of Education and Science of Ukraine № 1041; 2007 November. 27. Liga: zakon. 2007.

28. On approval of the State standard of primary general education of children in need of correction of physical and (or) mental development: Resolution of the Cabinet of Ministers of Ukraine № 848; 2013 Aug 21. KMU. 2013. 
29. On approval of measures for the introduction of inclusive education in preschool and secondary schools for the period up to 2015: Order of the Ministry of Education and Science of Ukraine № 1034; 2013 Aug 23. MES of Ukraine. 2013.

30. On approval of the concept of inclusive education development: Order of the Ministry of Education and Science of Ukraine № 912; 2010 Oct. 01. MES of Ukraine. 2010.

31. On approval of the action plan for 2017-2029 on the implementation of the Concept of implementation of state policy in the field of reforming general secondary education «New Ukrainian School»; Order of the Cabinet of Ministers of Ukraine № 903-r; 2019 April. 17. KMU. 2019.

32. On approval of the regulations on the individual form of education in secondary schools: Order of the Ministry of Education and Science of Ukraine № 732; 2019 Aug. 20; MES of Ukraine. 2020.

33. On approval of the procedure for the organization of inclusive education in secondary schools: Resolution of the Cabinet of Ministers of Ukraine № 872; 2011 Aug 15. KMU. 2011.

34. On the National Doctrine of Education Development: Decree of the President of Ukraine № 347/2002; 2002 April. 17. Official Gazette of the President of Ukraine. 2002.

35. On the National Strategy for the Development of Education in Ukraine until 2021: Decree of the President of Ukraine № 344/2013; 2013 Jun. 25. Official Gazette of the President of Ukraine. 2013.

36. On organizational and methodological principles of ensuring the right to education for children with special educational needs: Letter of the Ministry of Education and Science of Ukraine № 1 / 9-533; 2016 Jul. 12. MES of Ukraine. 2016

37. On the organization of inclusive education in out-of-school education institutions: Resolution of the Cabinet of Ministers of Ukraine № 779; 2019 Aug. 21. KMU. 2019.

38. On the organization of inclusive education in secondary schools: Letter of the Ministry of Education and Science of Ukraine № 1/ 9-384; 2012 May 5. MES of Ukraine. 2012.

39. On holding parliamentary hearings on the topic: «Education, health care and social security of children with mental and physical disabilities: problems and ways to solve them»: Resolution of the Verkhovna Rada of Ukraine № 1158-VII; 2014 Mar. 25. VVR № 23. 2014.

40. On the Recommendations of the Parliamentary Hearings on the topic: "Education, health care and social security of children with mental and physical disabilities: problems and ways to solve them": Resolution of the Verkhovna Rada of Ukraine № 96 - VIII; 2015 Jan. 01. VVR № 10. 2015.

41. On creating conditions for ensuring the right to education of persons with disabilities: Order of the Ministry of Education and Science of Ukraine № 691; 2005 Dec. 02; MON of Ukraine. 2005.

42. Chaykovskyi MI. Theort and practice of sociopedagogical work with youth with disabilities under conditions of inclusive educational environment [dissertation]. Starobilsk: «Luhanskyi natsionalnyi universytet imeni Tarasa Shevchenka»; 2016. 570 p.

43. Chernichenko LA. Inclusive education as a modern educational innovation. Molodyi vchenyi. $2016 ; 39$ (12): $537-541$.

44. Shevtsiv ZM. The impact of the legal framework of inclusive education on the preparation of future teachers to work in an inclusive environment of secondary school. Narodna osvita. 2017. 2: 10-16.

45. Regarding methodological recommendations for teaching children with special educational needs in 2019/2020. Letter of the Ministry of Education and Science of Ukraine № 1 / 9-498; 2019 Aug. 5. MES of Ukraine. 2019.

46. Armstrong F., Armstrong D., Barton L. Inclusive education: policy, contexts and comparative perspectives. Routledge. 2016: 176 p.

47. O'Hanlon C. Inclusive education in Europe. Routledge. 2017: 164 p.

48. Raymond E. B. Learners with mild disabilities: A characteristics approach. Pearson. 2016: 317 p.

\section{Інформація про авторів}

Когут Ірина Олександрівна, https:orcid.org/0000-0002-8862-9545, kogut_irina@ukr.net,

Маринич Вікторія Леонідівна https:orcid.org/0000-0003-2784-680X wikleon@ukr.net

Чебанова Катерина Вікторівна https:orcid.org/0000-0003-4601-2130, jkasniper@gmail.com

Національний університет фізичного виховання і спорту України, 03150, Київ, вул. Фізкультури, 1.

\section{Information about the authors}

Kogut Iryna,

https:orcid.org/0000-0002-8862-9545,

kogut_irina@ukr.net,

Marynych Viktoriia

https:orcid.org/0000-0003-2784-680X

wikleon@ukr.net

Chebanova Kateryna

https:orcid.org/0000-0003-4601-2130,

jkasniper@gmail.com

National University

of Ukraine on Physical Education and Sport,

03150, Kyiv, Fizkul'tury str., 1. 